\title{
HUBUNGAN ANTARA KELEKATAN ORANGTUA DENGAN REGULASI EMOSI REMAJA PONDOK PESANTREN AGRO "NUUR EL-FALAH" SALATIGA
}

\author{
Rahma Ajeng Pawulan', JT. Lobby Loekmono², Sapto Irawan ${ }^{3}$ \\ Program Studi S1 Bimbingan dan Konseling Universitas Kristen Satya Wacana ${ }^{1}$ \\ Pascasarjana, Magister Manajemen Pendidikan Universitas Kristen Satya \\ Wacana $^{2}$ \\ Program Studi S1 Bimbingan dan Konseling Universitas Kristen Satya Wacana ${ }^{3}$ \\ (email):132014067@student.uksw.edu ${ }^{1}$,lobby.loekmono@staff.uksw.edu², \\ sapto@staff.uksw.edu ${ }^{3}$
}

\begin{abstract}
This study aims to determine the sicnificance of the relationship between parent attachment and emotional regulation of adolescents Agro "Nuur El-Falah" Islamic Boarding School, Salatiga, Central Java. The subjects of this study were 123 students of the Salatiga Agro "Nuur El-Falah" Islamic Boarding School who were at the high school / vocational high school level. Data collection tools used are the Emotion Regulation Questionnaire by Gross and John (2003) and the Inventory of Parent and Peer Attachment by Armsden and Greenberg (2009). The analysis used is Pearson Product Moment Correlation analysis using SPSS version 20.0. The results of data analysis show that there is a significant positive relationship between parent attachment and emotional regulation. Correlation value ( $r$ ) between mother attachment with emotion regulation is $0,453(P=0,000<0,05)$ and correlation coefficient value $(r)$ father attachment with emotion regulation is $0,492(P=0,000<0,05)$.
\end{abstract}

Keywords : Parent Attachment, Emotion Regulation, Adolescents

\section{PENDAHULUAN}

Pada masa remaja, individu dihadapkan pada tantangan untuk menemukan siapa dirinya, bagaimana mereka nantinya, dan arah mana yang hendak mereka tempuh dalam hidupnya. Ini merupakan tahap kelima perkembangan menurut Erikson (1968). Dalam situasi ini, remaja dihadapkan dalam suatu krisis. Mampu mengontrol emosi seseorang merupakan aspek penting perkembangan remaja (Giedddalam
Santrock, 2009). Kemampuan mengelola dan mengekspresikan emosi merupakan salah satu bagian dari kemampuan regulasi emosi seseorang, selain proses memonitoring dan evaluasi reaksi terhadap emosi (Thompson, 1994; Zimmerman, 2001).

Gross (1998) menyatakan bahwa regulasi emosi merupakan proses di mana individu mempengaruhi emosi yang mereka miliki, saat mereka memilikinya dan bagaimana mereka mengalami serta 
mengekspresikan emosi-emosi ini. Dengan regulasi emosi individu dapat meredam, mengintensifkan, atau hanya mempertahankan emosi, tergantung pada tujuan individu tersebut (Gross \& Thompson, 2007). Cassidy (1994) mengungkapkan bahwa salah satu pengaruh pada perbedaan individu dalam regulasi emosi kemungkinan dilatarbelakangi oleh sejarah kelekatan/ attachment.

Attachment merupakan fondasi bagi pengembangan kapasitas individu untuk mengelola, mengenali dan mengatur emosi mereka secara adaptif dan mengatasi peristiwaperistiwa yang memicu stres. Meskipun teori ini menunjukkan keterikatan dan regulasi emosi dikaitkan dengan masa bayi, koneksi tersebut juga telah diselidiki pada masa remaja ataupun orang dewasa (Zimmer, Gembeck et al., 2015). Teori kontemporer mengemukakan tentang peran pengasuhan dan hubungan keluarga terhadap regulasi emosi, stres dan coping pada anak dan remaja (Allen \& Miga dalam Zimmer, Gembeck et al., 2015).

Hubungan anak dengan orang tua merupakan sumber emosional dan kognitif bagi anak (Ervika, 2005).Orangtua adalah pihak yang dapat membantu anak-anak mengatur emosi mereka (Thompsondalam Santrock, 2007). Melalui interaksi dengan orangtua, anak belajar untuk mengekspresikan emosinya dengan cara yang wajar (Santrock, 2007). Penerimaan dan dukungan orangtua terhadap emosi anak berhubungan dengan kemampuan anak untuk mengelola emosi dengan cara yang positif (Parke dalam Santrock, 2007).

Dalam hubungan antara orangtua dan anak dapat terjadi dua kemungkinan kelekatan, yakni kelekatan aman dan kelekatan tidak aman (Ervika, 2005). Kelekatan yang aman pada orangtua dalam masa remaja bisa membantu kompetensi sosial dan kesejahteraan remaja, seperti tercermin pada ciri seperti harga diri, penyesuaian emosional dan kesehatan fisik (Allen dkk., 2003 dalam Santrock, 2007). Dalam penelitian Joseph Allen dan koleganya, remaja yang lekat secara aman memiliki kemungkinan yang lebih rendah untuk melakukan perilaku bermasalah (Santrock, 2007). Kelekatan yang aman, atau 
keterhubungan dengan orangtua, menumbuhkan hubungan sebaya yang kompeten dan hubungan yang dekat dan positif di luar keluarga (Cassidydalam Santrock, 2007.

Anak yang melekat secara aman, melalui interaksi berulang dengan pengasuh yang peka, luwes, dan mendorong berbagai emosi, dapat secara terbuka mengekspresikan emosi mereka, belajar (dalam hubungan kelekatan) cara efektif untuk mengelola emosi negatif. Dalam situasi yang penuh stres, mampu meringankan penderitaan mereka, dan kembali ke eksplorasi lingkungan (Contreras, J.M.et.al. 2000).Dengan demikian, perilaku kelekatan menjadi strategi sosial untuk regulasi emosi negatif. Melalui interaksi dengan pengasuh, anak-anak belajar bagaimana dan kapan mengekspresikan emosi (terutama emosi negatif), dan mereka belajar apakah ekspresi emosi negatif terhadap pengasuh, atau tampilan perilaku keterikatan ketika merasa stres, mengarah ke reaksi penghibur yang tepat atau penolakan (Zimmermann, Peter \& Maier, Markus \& Winter, Monika \&
Grossmann, Klaus; 2001). Dapat disimpulkan bahwa kelekatan memiliki peran yang sangat penting bagi perkembangan regulasi emosi individu.

Pondok Pesantren Agro "Nuur El-Falah" Salatiga merupakan salah satu pondok pesantrenyang ada di Kota Salatiga. Pondok Pesantren Agro "Nuur El-Falah" Salatiga terletak di Jalan Dipomenggolo, Pulutan, Kecamatan Sidorejo, Kota Salatiga, Provinsi Jawa Tengah 50716.Santri yang ada di Pondok Pesantren Agro "Nuur El-Falah" Salatiga berasal dari berbagai latar belakang keluarga yang tentunya tidak terlepas dari berbagai permasalahan yang mempengaruhi hubungan antara anak dengan orangtua.

Dari hasil prapenelitian yang dilakukan oleh peneliti diketahyui bahwa remaja Pondok Pesantren Agro "Nuur El-Falah" Salatiga memiliki kualitas kelekatan orangtua dalam kategori Tinggi namun regulasi emosi yang dimiliki dalam kategori Rendah. Sedangkan teori regulasi emosi Thompson (1991) menyatakan bahwa regulasi emosi 
juga melibatkan faktor external terhadap anak khususnya hubungan anak dengan orangtua. Pernyataan Thompson tentang sifat adaptif dari regulasi emosi berpusat pada pemikiran Bowlby bahwa regulasi emosi adaptif berkaitan dengan kelekatan. Teori kelekatan John Bowlby (1982) disebutkan bahwa kualitas hubungan kelekatan, mempengaruhi regulasi emosi anak yang adaptif, melalui harapan anak tentang perilaku dan ketersediaan pengasuh, baik secara fisik maupun emosional. Dapat dilihat bahwa terdapat kesenjangan antara hasil pra penelitian yang dilakukan oleh peneliti dengan kajian teori yang ada.

Penelitian sebelumnya yang dilakukan oleh Arviyenna (2015) menunjukkan bahwa tidak terdapat hubungan yang signifikan antara kelekatan orangtua dengan regulasi emosi remaja. Sedangkan penelitian yang dilakukan oleh Leli Muhlisah (2015) menunjukkan bahwa terdapat hubugan positif yang signifikan antara kelekatan orangtua dengan regulasi emosi remaja. Kedua penelitian tersebut sama-sama mengacu pada hubungan kelekatan orangtua dan regulasi emosi remaja. Namun dapat dilihat bahwa terdapat hasil penelitian yang bertentangan mengenai hubungan antara kelekatan orangtua dengan regulasi emosi remaja pada kedua penelitian tersebut.

Penelitian ini bertujuan untuk mengetahui signifikansi hubungan antara kelekatan kepada orangtua dengan regulasi emosi remaja Pondok Pesantren Agro "Nuur ElFalah" Salatiga.

Regulasi emosi merupakan proses dimana individu mempengaruhi emosi yang mereka miliki, saat mereka memilikinya dan bagaimana mereka mengalami serta mengekspresikan emosi-emosi ini (Gross, 1998). Proses regulasi emosi mengacu pada serangkaian proses yang disebut dengan proses emosi generatif yang terlibat dalam pembentukan emosi, dan masingmasing memiliki potensi untuk meregulasi emosi. Serangkaian proses ini terdiri atas 5 (lima) poin, yakni (1) situasion selection, (2) situation modification, (3) attentional deployment, (4) cognitive change dan(5) response modulation (Gross, 
1998b, 2007).Dengan regulasi emosi individu dapat meredam, mengintensifkan, atau hanya mempertahankan emosi, tergantung pada tujuan individu tersebut (Gross \& Thompson, 2007). Dengan kemampuan regulasi emosi individu dapat menilai, mengatasi, mengelola dan mengungkapkan emosi yang tepat dalam rangka mencapai keseimbangan emosional (Gross, 1998b; Richard \& Gross, 2000).

Peneliti menyimpulkan bahwa regulasi emosi merupakan kemampuan individu untuk mempengaruhi emosi yang mereka miliki. Iindividu dapat meredam, mengintensifkan ataupun mempertahankan emosi mereka, sehingga individu dapat mengendalikan dampak emosional yang dimungkinkan muncul atas emosi yang mereka miliki saat ini.

Terdapat (4) empat faktor yang mempengaruhi regulasi emosi, yakni : sosialisasi emosi (John \& Gross, 2004), tempramen dan kepribadian (John \& Gross, 2004), usia (Urry \& Gross, 2010), serta kelekatan (John $\&$ Gross, 2007).
Gross \& John

(2003) menemukan dua strategi spesifik dari regulasi emosi yakni cognitive reappraisal dan expressive suppression. Cognitive Reappraisal (CR), merupakan perubahan cara berpikir seseorang tentang situasi yang berpotensi menimbulkan emosi untuk mengubah dampak emosionalnya (Gross \& John, 2004). Sedangkan Expressive Suppression (ES), merupakan suatu bentuk response modulation yang melibatkan penghambatan emosi yang sedang berlangsung. Expressive Suppression melibatkan pengurangan perilaku ekspresif emosi begitu individu sudah dalam keadaan emosional (Gross \& John, 2004).

Bowlby (1982) mendefinisikan kelekatan sebagai ikatan emosional yang kuat dari satu orang ke orang lain yang penting dan bermakna. Menurut Ainsworth (1969 dalam Mc Certnay \& Dearing, 2002) attachment adalah ikatan emosional yang dibentuk seorang individu dengan orang lain yang bersifat spesifik, mengikat mereka dalam suatu attachment yang bersifat kekal sepanjang waktu. Penulis 
menyimpulkan bahwa kelekatan (Attachment) merupakan suatu hubungan emosional ataupun hubungan yang bersifat afeksi antara satu individu dengan individu lainnya yang memiliki arti khusus, biasanya orangtua. Hubungan ini tidak hanya berasal dari dukungan fisik tetapi juga berasal dari dukungan psikologis dari figur lekat. Kelekatan berawal dari masa bayi pada hubungan antara bayi dengan orangtua atau pengasuhnya, yang kemudian sejarah kelekatan ini yang menjadi dasar keamanan psikologi pada hubungan selanjutnya dan memberi pengaruh baik dari masa bayi, anak-anak, remaja hingga dewasa. Serta memberi pengaruh besar terhadap kesejahteraan individu.

Kelekatan tidak hanya penting untuk kesejahteraan umum (Kreppner \& Ullrich, 1998 dalam Barrocas, 2008), tetapi juga berfungsi sebagai dasar untuk semua hubungan di seluruh masa hidup (Waters, Merrick, Treboux, Rowell, \& Albershein dalam Barrocas, 2008). Menurut Jacobson dan Hoffman dalam Papalia, Olds \& Feldman
(2009), bila anak mendapatkan dasar aman dan dapat mempercayai respon orangtua, mereka akan merasa cukup percaya diri untuk melibatkan diri dari dunia mereka secara aktif. Anak dengan kelekatan tidak aman cenderung akan menunjukkan emosi negatif (rasa takut, distress dan marah), sementara anak dengan kelekatan aman terlihat lebih ceria (Koshanska dalam Papalia, Olds \& Feldman, 2009).

Armsden \& Greenberg (1987) mengacu pada teori kelekatan Bowlby (1973) tentang perasaan alami terhadap figur lekat (baik orangtua ataupun rekan) mengungkapkan tiga dimensi kelekatan yaitu, tingkat saling percaya (degree of mutual trust), kualitas komunikasi (quality of communication) dan tingkat kemarahan dan keterasingan (extent of anger and alienation). Rasa percaya (trust) dan komunikasi (communication) memiliki nilai positif yang akan menunjukkan atau mendukung adanya kelekatan remaja pada figur lekat. Sedangkan aspek pengasingan (alienation) megandung penilaian yang berbeda dengan dua 
aspek sebelumnya karena menunjukkan nilai yang negatif sehingga kurang mendukung dan menunjukkan adanya kelekatan (Armsden \& Greenberg, 1987).

Ditinjau dari pelaksanaannya, pesantren merupakan boarding school/sekolah asrama. Hal tersebut didasarkan pada teori Bamford, (1967) dalam Rasyid (2012), sekolah berasrama (boarding school) adalah sekolah yang didalamnya terdapat fasilitas penginapan yang disediakan untuk siswanya dan fasilitas tersebut dalam lokasi yang berdekatan dengan fasilitas sekolah. Di sekolah berasrama, siswa-siswi tidur, makan dan bekerja atau melakukan aktivitas dekat dengan lingkungan sekolah (Bamford, 1967; dalam Rasyid, 2012).

Perpecahan awal antara anak dengan keluarga memiliki pengaruh terhadap pola kelekatan (Schaverien, 2015) yang akan berpengaruh pula pada regulasi emosi. Schaverien (2011a) menjelaskan bahwa kehilangan figur kelekatan secara mendadak (orang tua, saudara, hewan peliharaan dan mainan) menyebabkan anak berusaha untuk melindungi dirinya sendiri. Anak itu kemudian tidak membuat tuntutan emosional tetapi juga tidak lagi mengakui kebutuhan untuk keintiman. Kemudian diri menjadi mulai tidak dapat diakses; 'Sindrom Boarding School' berkembang (Schaverien, 2011a). Schaverine (2011b) mengidentifikasi Boarding School Syndrome sebagai seperangkat pola yang dapat dikenali. Pola ini merupakan dampak dari awal pengasramaan yang merusak hubungan anak dengan dirinya sendiri dan sebagai konsekuensinya adalah ketidakmampuan untuk membicarakan tentang perasaannya

Siswa yang berada di bawah perawatan rutin (misalnya, harian) oleh orang tua dan rumah ditempatkan dengan baik untuk membentuk kelekatan yang diperlukan untuk perkembangan yang sehat. Dalam konteks ini, sekolah asrama dapat menjauhkan anak-anak muda dari pengaruh penting ini dan menyebabkan efek negatif relatif pribadi dan interpersonal (non-akademik) dari boarding school.Namun, sejauh ini terjadi, sekolah asrama juga dapat 
menjauhkan siswa lain dari orangtua yang berpotensi negatif dan lingkungan rumah ataupun lingkungan sekitar yang tidak baik (Bowlby, 1952 dalam Papworth, 2014). Bowlby (1952, Papworth, 2014) menganggap asrama sesuai untuk anak-anak yang lebih besar, terutama jika anak tersebut malsuai atau dari keluarga dan lingkungan hidup yang sulit.

\section{METODE PENELITIAN}

Metode penelitian yang digunakan dalam penelitian ini adalah metode kuantitatif. Metode kuantitatif dilakukan pada penelitian inferensial, yakni penelitian yang dilakukan dalam rangka pengujian hipotesis dan menyandarkan kesimpulan pada suatu probabilitas kesalahan penolakan hipotesis nihil. Maka dengan metode kuantitatif ini akan diperoleh signifikansi hubungan antar variabel yang diteliti.

Sedangkan jenis penelitian yang digunakan dalam penelitian ini merupakan jenis penelitian korelasional.

Populasi dari penelitian ini adalah santri usia SMA/SMK Pondok Pesantren Agro "Nuur El-
Falah" Salatiga yakni sebanyak 187 orang.

Teknik sampling yang digunakan adalah teknik simple random sampling yakni pengambilan anggota sampel dari populasi dilakukan secara acak tanpa memperhatikan strata yang ada dalam populasi itu (Sugiyono, 2015. Penentuan jumlah sampel dalam penelitian ini berdasarkan pada tabel Isaac\&Michael (Sugiyono, 2015). Karena jumlah populasi sebanyak 187 yang lebih mendekati angka 190 . Maka melalui tabel Isaac \& Michael (Sugiyono, 2015) dengan taraf kesalahan sebesar $5 \%$ dan jumlah populasi sebesar 190 orang didapatkan sampel sebesar 123 orang. Sehingga sampel yang digunakan dalam penelitian ini adalah sebanyak 123 santri yang berada jenjang pendidikan SMA/SMK Pondok Pesantren Agro "Nuur El-Falah" Salatiga yang diambil secara acak.

Teknik pengumpulan data yang digunakandalam penelitian ini yakniEmotion Regulation Questionnaire for Children and Adolescents (ERQ-CA) dari Gullone 
\& Teffa (2011). Yang digunakan untuk mengukur regulasi emosi remaja. Serta Inventory of Parent and Peer Attachment (IPPA)-Revised yang disusun oleh Armsden, G, C., \& Greenberg, M, T (2009)untuk mengukur kelekatan orangtua.

Dari hasil perhitungan SPSS 20 for Windows, penulis melihat Corrected Item-Total Correlation untuk menentukan validitas item. Dengan hasil keseluruhan item dalam instrument kelekatan ibu, instrument kelekatan ayah dan instrument regulasi emosi dinyatakan valid. Hal itu dapat dilihat dari Corrected Item-Total Correlation setiap item $\geq 0,2$.

Variabel dalam penelitian ini adalah regulasi emosi sebagai variabel (Y) atau variabel terikat dan kelekatan orangtua sebagai variabel (X) atau variabel bebas. Jenis data dari kedua variabel tersebut adalah ordinal. Sehingga analisis korelasi yang digunakan adalah analisis Pearson Corelation Product Moment. Dalam penelitian ini digunakan taraf signifikansi sebesar $0,05(\alpha=0,05)$.

\section{HASIL DAN PEMBAHASAN}

\section{Gambaran Subjek Penelitian}

Penelitian ini dilaksanakan di Pondok Pesantren Agro "Nuur ElFalah" Salatiga terletak di Jalan Dipomenggolo, Pulutan, Kecamatan Sidorejo, Kota Salatiga, Provinsi Jawa Tengah 50716. Subjek penelitian ini adalah santri pondok pesantren yang berada pada jenjang pendidikan SMA/SMK yang berjumlah 123 orang santri.

Tabel 1. Jumlah santri usia SMA/SMK PondokPesantren Agro "Nuur El-Falah" Salatiga Berdasarkan Strata Kelas

\begin{tabular}{|c|c|c|c|}
\hline $\begin{array}{c}\text { No } \\
\text {. }\end{array}$ & $\begin{array}{l}\text { Strat } \\
\text { a } \\
\text { Kelas }\end{array}$ & $\begin{array}{c}\text { Jumla } \\
\mathbf{h}\end{array}$ & $\begin{array}{c}\text { Persentas } \\
\text { e }\end{array}$ \\
\hline 1. & $\begin{array}{l}\text { Kelas } \\
\text { X }\end{array}$ & 53 & $43 \%$ \\
\hline 2. & $\begin{array}{l}\text { Kelas } \\
\text { XI }\end{array}$ & 43 & $35 \%$ \\
\hline 3. & $\begin{array}{l}\text { Kelas } \\
\text { XII }\end{array}$ & 27 & $22 \%$ \\
\hline \multicolumn{2}{|c|}{ Jumlah } & 123 & $100 \%$ \\
\hline
\end{tabular}

Tabel 1 menunjukkan bahwa subjek penelitian sebagian besar berada pada strata kelas X (sepuluh) SMA/SMK (43\%).

Tabel 2. Jumlah santri usia SMA/SMK

Pondok Pesantren Agro "Nuur El-Falah" Salatiga Berdasarkan Jenis Kelamin

\begin{tabular}{cccc}
\hline No & $\begin{array}{c}\text { Strata } \\
\text { Kelas }\end{array}$ & $\begin{array}{c}\text { Jumla } \\
\text { h }\end{array}$ & $\begin{array}{c}\text { Persenta } \\
\text { se }\end{array}$ \\
\hline 1. & Laki-laki & 70 & $57 \%$ \\
\hline $\begin{array}{l}\text { 2. } \\
\text { Perempu } \\
\text { an }\end{array}$ & 53 & $43 \%$ \\
\hline
\end{tabular}




\section{$\begin{array}{lll}\text { Jumlah } & 123 & 100 \%\end{array}$}

Tabel 2 menunjukkan bahwa

sebagian besar subjek penelitian

berjenis kelamin laki-laki (57\%).

\section{Analisis Deskriptif}

Tabel 3. Kategori Kelekatan kepada Ibu

\begin{tabular}{cccc}
\multicolumn{4}{c}{ (Mother Attachment) } \\
\hline $\begin{array}{c}\text { Kateg } \\
\text { ori }\end{array}$ & $\begin{array}{c}\text { Interv } \\
\text { al }\end{array}$ & $\begin{array}{c}\text { Frekue } \\
\text { nsi }\end{array}$ & $\%$ \\
\hline $\begin{array}{c}\text { Sangat } \\
\text { Renda }\end{array}$ & $25-39$ & 0 & $0 \%$ \\
& & &
\end{tabular}

\begin{tabular}{clcc}
$\mathrm{h}$ & & & \\
\hline $\begin{array}{c}\text { Renda } \\
\mathrm{h}\end{array}$ & $40-54$ & 0 & $0 \%$ \\
\hline $\begin{array}{c}\text { Sedan } \\
\mathrm{g}\end{array}$ & $55-69$ & 15 & $\begin{array}{c}12,2 \\
\%\end{array}$ \\
\hline Tinggi & $70-84$ & 95 & $\begin{array}{c}77,3 \\
\%\end{array}$ \\
\hline Sangat & $85-$ & 13 & $\begin{array}{c}10,5 \\
\%\end{array}$ \\
Tinggi & 100 & &
\end{tabular}

\begin{tabular}{|c|c|c|}
\hline Jumlah & 123 & $100 \%$ \\
\hline
\end{tabular}

bahwa sebagian besar remaja Pondok

Pesantren Agro "Nuur El-Falah"

Salatiga memiliki kelekatan kepada

Ibu (Mother Attachment) dalam

kategori Tinggi ( 77,3\%).

Table 4. Kategori Kelekatan kepada Ayah (Father Attachment)

\begin{tabular}{cccc}
\hline $\begin{array}{c}\text { Katego } \\
\text { ri }\end{array}$ & $\begin{array}{c}\text { Interv } \\
\text { al }\end{array}$ & $\begin{array}{c}\text { Frekuen } \\
\text { si }\end{array}$ & \% \\
\hline $\begin{array}{c}\text { Sangat } \\
\text { Rendah }\end{array}$ & $25-39$ & 0 & $0 \%$ \\
\hline Rendah & $40-54$ & 4 & $\begin{array}{c}3,3 \\
\%\end{array}$ \\
\hline Sedang & $55-69$ & 25 & $\begin{array}{c}20,3 \\
\%\end{array}$ \\
\hline Tinggi & $70-84$ & 82 & 66,7 \\
\hline
\end{tabular}

\begin{tabular}{lccc}
\hline & & & $\%$ \\
\hline Sangat & $85-$ & 12 & 9,7 \\
Tinggi & 100 & & $\%$ \\
\hline \multicolumn{2}{c}{ Jumlah } & 123 & $\begin{array}{c}100 \\
\%\end{array}$ \\
\hline
\end{tabular}

Pada tabel 4 menunjukkan bahwa sebagian besar remaja Pondok Pesantren Agro "Nuur El-Falah" Salatiga memiliki kelekatan kepada Ayah (Father Attachment) dalam kategori Tinggi ( 66,7\% ).

Dari data tabel 3 Kelekatan kepada Ibu (Mother Attachment), dan table 4 Kelekatan kepada Ayah (Father Attachment), tersebut dapat diketahui bahwa remaja Pondok Pesantren Agro "Nuur El-Falah" Salatiga memiliki kelekatan orangtua dalam kategori Tinggi.

Table 5. Kategori Regulasi Emosi

\begin{tabular}{|c|c|c|c|}
\hline $\begin{array}{c}\text { Katego } \\
\text { ri }\end{array}$ & $\begin{array}{c}\text { Interva } \\
\mathbf{l}\end{array}$ & $\begin{array}{c}\text { Frekuens } \\
\mathbf{i}\end{array}$ & $\mathbf{\%}$ \\
\hline $\begin{array}{c}\text { Sangat } \\
\text { Rendah }\end{array}$ & $10-15$ & 0 & $0 \%$ \\
& & & \\
\hline Rendah & $16-21$ & 30 & $\begin{array}{c}24, \\
4 \%\end{array}$ \\
\hline Sedang & $22-27$ & 34 & $\begin{array}{c}27 \\
6 \%\end{array}$ \\
\hline Tinggi & $28-33$ & 45 & 36, \\
& & & $6 \%$ \\
\hline Sangat & $34-40$ & 14 & 11, \\
Tinggi & & & $4 \%$ \\
& & & \\
\hline
\end{tabular}




\begin{tabular}{|c|c|c|}
\hline Jumlah & 123 & $\begin{array}{c}100 \\
\%\end{array}$ \\
\hline
\end{tabular}

Pada tabel 5 menunjukkan bahwa sebagian besar remaja Pondok Pesantren Agro "Nuur El-Falah" Salatiga memiliki regulasi emosi dalam kategori Tinggi( $36,6 \%$ ).

\section{Uji Normalitas}

Table 6. Uji Normalitas Variabel Kelekatan kepada Ibu, Variabel Kelekatan kepada Ayah dan Variabel Regulasi Emosi

\begin{tabular}{|c|c|c|c|c|}
\hline \multicolumn{5}{|c|}{ One-Sample Kolmogorov-Smirnov Test } \\
\hline & & $\begin{array}{l}\text { Mother } \\
\text { Attachm } \\
\text { ent }\end{array}$ & $\begin{array}{l}\text { Father } \\
\text { Attac } \\
\overline{\text { hment }}\end{array}$ & $\begin{array}{c}\text { Regul } \\
\text { asi_E } \\
\text { mosi }\end{array}$ \\
\hline $\mathrm{N}$ & & 123 & 123 & 123 \\
\hline \multirow{2}{*}{$\begin{array}{l}\text { Normal } \\
\text { Parameter } \\
\mathrm{s}^{\mathrm{a}, \mathrm{b}}\end{array}$} & Mean & 77.1301 & $\begin{array}{r}74.292 \\
7\end{array}$ & $\begin{array}{r}26.91 \\
06\end{array}$ \\
\hline & $\begin{array}{l}\text { Std. } \\
\text { Deviati } \\
\text { on }\end{array}$ & 6.91868 & $\begin{array}{r}9.2273 \\
0\end{array}$ & $\begin{array}{r}5.095 \\
82\end{array}$ \\
\hline \multirow{3}{*}{$\begin{array}{l}\text { Most } \\
\text { Extreme } \\
\text { Differences }\end{array}$} & $\begin{array}{l}\text { Absolut } \\
\mathrm{e}\end{array}$ & .055 & .100 & .121 \\
\hline & Positive & .055 & .055 & .121 \\
\hline & $\begin{array}{l}\text { Negativ } \\
\mathrm{e}\end{array}$ & -.048 & -.100 & -.069 \\
\hline \multicolumn{2}{|c|}{$\begin{array}{l}\text { Kolmogorov-Smirnov } \\
\text { Z }\end{array}$} & .606 & 1.114 & 1.340 \\
\hline \multicolumn{2}{|c|}{$\begin{array}{l}\text { Asymp. Sig. (2- } \\
\text { tailed) }\end{array}$} & .856 & .167 & .055 \\
\hline \multicolumn{5}{|c|}{ a. Test distribution is Normal. } \\
\hline
\end{tabular}

Pada tabel 6 Variabel

kelekatan kepada ibu diperoleh nilai Kolmogorov-Smirnov (KS Z)sebesar 0.606 dengan Asymp. Sig (2-tailed) sebesar $0,856>0,05$. Variabel kelekatan kepada ayah diperoleh nilai Kolmogorov-Smirnov (KS
Z)sebesar 1.114 dengan Asymp. Sig (2-tailed) sebesar $0,167>0,05$. Variabel regulasi emosi diperoleh nilai Kolmogorov-Smirnov (KS Z)sebesar 1.340 dengan Asymp. Sig (2-tailed) sebesar $0,055>0,05$. Seluruh variabel memiliki nilai Asymp. Sig (2-tailed) > 0,05 sehingga variabel kelekatan kepada ibu,variabel kelekatan kepada ayah dan variabel regulasi emosi dapat dikatakan memiliki distribusi normal.

\section{Analisis Korelasional}

Table 7. Korelasi Kelekatan Kepada Ibu dengan Regulasi Emosi

\begin{tabular}{llrr}
\hline \multicolumn{4}{c}{ Correlations } \\
\hline & & $\begin{array}{c}\text { Mother } \\
\text { Attach } \\
\text { ment }\end{array}$ & $\begin{array}{r}\text { Regula } \\
\text { si_Emo } \\
\text { si }\end{array}$ \\
\hline & $\begin{array}{l}\text { Pearson } \\
\text { Correlation }\end{array}$ & 1 & $.453^{* *}$ \\
\cline { 2 - 4 } $\begin{array}{l}\text { Mother_At } \\
\text { tachment }\end{array}$ & $\begin{array}{l}\text { Sig. (2- } \\
\text { tailed) }\end{array}$ & & .000 \\
\cline { 2 - 4 } & $\mathrm{N}$ & 123 & 123 \\
\hline & $\begin{array}{l}\text { Pearson } \\
\text { Correlation }\end{array}$ & $.453^{* *}$ & 1 \\
\cline { 2 - 4 } $\begin{array}{l}\text { Regulasi_- } \\
\text { Emosi }\end{array}$ & $\begin{array}{l}\text { Sig. (2- } \\
\text { tailed) }\end{array}$ & .000 & \\
\cline { 2 - 4 } & $\mathrm{N}$ & 123 & 123 \\
\hline **. Correlation is significant at the 0.01 \\
level (2-tailed).
\end{tabular}

Pada tabel 7. menunjukkan

bahwa terdapat hubungan positif yang signifikan antara kelekatan kepada ibu dengan regulasi emosi, dengan nilai koefisien korelasi sebesar 0,453 dan $\mathrm{P}=0.000<0,05$. 
Table 8. Korelasi Kelekatan Kepada Ayah dengan Regulasi Emosi Correlations

\begin{tabular}{|c|c|c|c|}
\hline & & $\begin{array}{c}\text { Father } \\
\text { Attach } \\
\text { ment }\end{array}$ & $\begin{array}{l}\text { Regula } \\
\text { si_Emo } \\
\text { si }\end{array}$ \\
\hline \multirow[b]{2}{*}{$\begin{array}{l}\text { Father_At } \\
\text { tachment }\end{array}$} & $\begin{array}{l}\text { Pearson } \\
\text { Correlation }\end{array}$ & 1 & $.492^{* *}$ \\
\hline & $\begin{array}{l}\text { Sig. }(2- \\
\text { tailed) }\end{array}$ & & .000 \\
\hline \multirow{4}{*}{$\begin{array}{l}\text { Regulasi_ } \\
\text { Emosi }\end{array}$} & & 123 & 123 \\
\hline & $\begin{array}{l}\text { Pearson } \\
\text { Correlation }\end{array}$ & $.492^{\star *}$ & 1 \\
\hline & $\begin{array}{l}\text { Sig. }(2- \\
\text { tailed) }\end{array}$ & .000 & \\
\hline & $\mathrm{N}$ & 123 & 123 \\
\hline
\end{tabular}

${ }^{* *}$. Correlation is significant at the 0.01 level (2-tailed).

Pada tabel 8. menunjukkan bahwa terdapat hubungan positif yang signifikan antara kelekatan kepada ayah dengan regulasi emosi, dengan nilai koefisien korelasi sebesar 0,492 dan $\mathrm{P}=0.000<0,05$.

\section{Uji Hipotesis}

Dari hasil analisis korelasi diketahui bahwa antara kelekatan kepada ibu dengan regulasi emosi memiliki nilai koefisien korelasi sebesar 0,453 dan $\mathrm{P}=0.000<$ 0,05dan antara kelekatan kepada ayah dengan regulasi emosi memiliki nilai koefisien korelasi sebesar 0,492 dan $\mathrm{P}=0.000<0,05$. Yang menunjukkan bahwa terdapat hubungan yang signifikan antara kelekatan orangtua dengan regulasi emosiremaja Pondok Pesantren Agro
"Nuur El-Falah" Salatiga sehingga hipotesis yang diajukan diterima.

\section{Pembahasan}

Dari hasil uji korelasi yang dilakukan dapat diketahui bahwa terdapat hubungan positif yang signifikan antara kelekatan orangtua dengan regulasi emosi remaja Pondok Pesantren Agro "Nuur ElFalah" Salatiga. Yang artinya semakin tinggi skor kelekatan orangtua semakin tinggu skor regulasi emosi, dan semakin rendah skor kelekatan orangtua semakin rendah skor regulasi emosi.

Temuan ini didukung oleh teori regulasi emosi John \& Gross (2007) yang sepakat dengan teori kelekatan Bowlby yang memprediksi adanya hubungan yang erat antara kelekatan dengan penggunaan strategi regulasi emosi. Ditunjukkan bahwa kelekatan berasal dari kebutuhan anak untuk mengatur kecemasan yang muncul dari pola hubungan awal dengan cargiver. Cassidy (1994) juga mengungkapkan bahwa salah satu pengaruh pada perbedaan individu dalam regulasi emosi kemungkinan dilatarbelakangi oleh sejarah kelekatan/ attachment. 
Thompson

menambahkan bahwa regulasi emosi juga melibatkan faktor external terhadap anak khususnya hubungan anak dengan orangtua. Pernyataan Thompson tentang sifat adaptif dari regulasi emosi yang juga berpusat pada pemikiran Bowlby bahwa regulasi emosi adaptif berkaitan dengan kelekatan. Teori kelekatan John Bowlby (1982) menyebutkan bahwa kualitas hubungan kelekatan, mempengaruhi regulasi emosi anak yang adaptif, melalui harapan anak tentang perilaku dan ketersediaan pengasuh, baik secara fisik maupun emosional.

Selain kelekatan, Gross menyatakan bahwa regulasi emosi individu juga dipengaruhi oleh faktor sosialisasi emosi (John \& Gross, 2004), tempramen dan kepribadian (John \& Gross, 2004), usia (Urry \& Gross, 2010), serta kelekatan (John \& Gross, 2007).

Selanjutnya dari hasil analisis deskriptif dapat diketahui bahwa santri memiliki kelekatan orangtua pada kategori Tinggi. Hal tersebut dapat dipengaruhi oleh dua faktor yakni pertama, subjek penelitian sebagian besar adalah santri usia kelas X (sepuluh) yang baru saja memasuki pondok pesantren, sehingga dimungkinkan kelekatan orangtua yang dimiliki masih tinggi. Kedua, pondok pesantren menyediakan waktu kepada orangtua santri untuk menjenguk anaknya setiap hari jum'at. Dengan demikian komunikasi antara santri dan orangtua tetap terjalin dengan baik. Komunikasi (communication) merupakan salah satu aspek kekelatan yang memiliki nilai positif serta akan menunjukkan atau mendukung adanya kelekatan remaja pada figur lekat (Armsden \& Greenberg, 1987).

Penelitian lain juga mengungkapkan bahwa attachment merupakan fondasi bagi pengembangan kapasitas individu untuk mengelola, mengenali dan mengatur emosi mereka secara adaptif dan mengatasi peristiwaperistiwa yang memicu stress (Zimmer, Gembeck et al., 2015).Anak yang melekat secara aman, melalui interaksi berulang dengan pengasuh yang peka, luwes, dan mendorong berbagai emosi, 
dapat secara terbuka mengekspresikan emosi mereka, belajar (dalam hubungan kelekatan) cara efektif untuk mengelola emosi negatif. Dalam situasi yang penuh stres, mampu meringankan penderitaan mereka, dan kembali ke eksplorasi lingkungan (Contreras, J.M.et.al. 2000).

Penelitian terkait lainnya yang mendukung hasil penelitian ini adalah penelitian oleh Biesecker (2001) yang mengungkapkan bahwa tingginya aspek kelekatan rasa percaya, komunikasi serta rendahnya pengasingan memiliki memprediksi penggunaan regulasi emosi yang adaptif. Dan rendahnya aspek rasa percaya dan komunikasi serta tingginya aspek pengasingan memprediksi penggunaan regulasi emosi yang maladaptif. Penelitian lain oleh Gresham \& Gullone (2012) juga menemukan hubungan yang signifikan antara kelekatan dengan regulasi emosi remaja.

Hasil penelitian ini sejalan dengan penelitian sebelumnya yakni penelitian oleh Leli Muhlisah (2015) yang menunjukkan bahwa terdapat hubungan positif yang signifikan antara kelekatan orangtua dengan regulasi emosi remaja. Persamaan hasil penelitian ini dimungkinkan karena persamaan teori yang digunakan. Teori yang digunakan adalah teori kelekatan dari Bowlby $(1968,1972)$ dan teori regulasi emosi dari Gross (1998). Dalam pengukuran variabel penelitian juga sama-sama menggunakan Inventory of Parent and Peer AttachmentRevised (Armsden \& Greenberg, 2009) guna mengukur kelekatan orangtua dan Emotion Regulation Questionnaire (Gross \& John, 2003) guna mengukur regulasi emosi.

Namun hasil penelitian ini berlawanan dengan penelitian yang dilakukan oleh Arviyenna (2015) yang menunjukkan bahwa tidak terdapat hubungan yang signifikan antara kelekatan orangtua dengan regulasi emosi remaja. Perbedaan hasil penelitian ini dimungkinkan karena adanya perbedaan alat ukur yang digunakan dalam pengukuran regulasi emosi. Alat ukur yang digunakan oleh Arviyenna (2015) adalah Cognitive Emotion Regulation Quetionnaire (Garnesfski \& Kraaij, 2007) sedangkan penelitian ini 
menggunakan Emotion Regulation

Questionnaire (Gross \& John, 2003).

Karena alat ukur yang digunakan berbeda maka berbeda pula aspekaspek yang diukur.

\section{SIMPULAN DAN SARAN}

\section{Simpulan}

Hasil penelitian ini dapat disimpulkan bahwa terdapat hubungan positif yang signifikan antara kelekatan orangtua dengan regulasi emosi remaja. Dengan nilai koefisien korelasi antara kelekatan kepada ibu dengan regulasi emosi sebesar 0,453 dan $\mathrm{P}=0.000<0,05$ dan nilai koefisien korelasi antara kelekatan kepada ayah dengan regulasi emosi sebesar 0,492 dan $\mathrm{P}=$ $0.000<0,05$. Hubungan yang positif menunjukkan bahwa semakin tinggi skor kelekatan orangtua semakin tinggi skor regulasi emosi, dan semakin rendah skor kelekatan orangtua semakin rendah skor regulasi emosi.

\section{Saran}

\section{Bagi Pondok Pesantren}

Dengan adanya hubungan yang signifikan antara kelekatan orangtua dengan regulasi emosi diharapkan pondok pesantren dapat melanjutkan atau tidak menghilangkan kebijakan untuk menyediakan waktu berkunjung bagi orangtua.

\section{Bagi Orangtua dan Santri}

Dengan adanya hubungan yang signifikan antara kelekatan orangtua dengan regulasi emosi diharapkan kepada orangtua serta santri untuk dapat meningkatkan kualitas pertemuan pada waktu yang telah disediakan oleh pihak pondok pesantren sehingga dapat meningkatkan kualitas kelekatan emosi antara anak dan orangtua.

\section{Bagi Peneliti Berikutnya}

Berdasarkan analisis variabel kelekatan orangtua dan regulasi emosi remaja ditemukan hubungan yang positif dan signifikan. Masukan bagi peneliti selanjutnya adalah untuk meneliti hubungan antara regulasi emosi dengan faktor-faktor lainnya yang mempengaruhi yaknifaktor sosialisasi emosi, tempramen dan kepribadian, usia, jenis kelamin. Merujuk pada penelitian terkait peneliti selanjutnya juga dapat melihat hubungan antara kelekatan orangtua dengan regulasi emosi yang lebih spesifik yakni 
Cognitive Reappraisal dan

Exspressive Suppression melihat adanya konsekuensi yang berbeda antara kedua strategi regulasi emosi tersebut.

\section{DAFTAR PUSTAKA}

Armsden, Gay C. \& Greenberg, Mark T. 1987. The Inventory of Parent and Peer Attachment: Individual Differences and Their Relationship to Psychological Well-Being in Adolescence. Journal of Youth and Adolescence 16(5):427-54. DOI: $10.1007 / \mathrm{BF} 02202939$.

Arviyenna, Sandra. 2015. Hubungan antara Parent Attachment dengan Regulasi Emosi Remaja di SMA Negeri 5 Surakarta. Salatiga : Universitas Kristen Satya Wacana.

Barrocas, Andrea L. 2008. Adolescent Attachment to Parents and Peers. The Emory Center for Myth and Ritual in American Life, Working Paper No. 50.

Biesecker, G. E. (2001). Attachment to Parents and Peers and Emotion Regulation in Middle Adolescence

(Doctoral Dissertation). Available from ProQuest Dissertations and Theses database (ATT 3017380).

Bowlby, J. (1982). Attachment and Loss, Vol. 1 Attachment. Attachment and Loss. New York Basic Books.
Cassidy, J. (1994). Emotion Regulation Influences of Attachment Relationships. In N. Fox (Ed.) p.228-249.

Contreras, J.M., et.al. 2000. Emotion Regulation as a Mediator of Associations Betwens MotherChild Attachment and Peer Relationships In Middle Childhood. Journal of family psychology, 14, 111-124. DOI: 10.1037/0893-3200.14.1.111.

Erikson, E. (1968). Identity: Youth and Crisis. New York: W. W. Norton \& Company.

Ervika, Eka. Kelekatan (Attachment) Pada Anak. Sumatra : Universitas Sematera Utara.

Gresham, D; Gullone. E. 2012. Emotion Regulation Strategy Use in Children and Adolescents. Personality and Individual Differences 52, pp 616-621.

DOI: 10.1016/j.paid.2011.12.016.

Gross, J. J. 1998a. Sharpening the Focus- Emotion Regulation, Arousal, and Social Competence. Psychological Inquiry Volume 9 issue 4. DOI: $10.2307 / 2$ F1449735.

Gross, J. J., \& John, O. P. (2003). Individual Differences in Two Emotional Regulastion Process Implications for Affect, Relationships, and Well-Being. Journal of Personality and Social Psychology, 2, 348-362. DOI: $10.1037 / 0022-$ 3514.85.2.348.

Gross, J. J., \& Muñoz, R. F. (1995). Emotion Regulation and 
Mental Health. Clinical Psychology: Science and Practice, 2(2), 151-164. DOI: $10.1111 /$ j. $1468-$ 2850.1995.tb00036.x.

Gross, J. J., \& Thompson, R. A. (2007). Emotion Regulation Conceptual Foundations. In J. J. Gross (Ed.).

Gullone, E. \& Taffe, J. 2011. The Emotion Regulation Questionnaire for Children and Adolescents (ERQ-CA): A Psychometric Evaluation. Psychological Assessment, Advance online publication. DOI: $10.1037 / \mathrm{a} 0025777$.

John \& Gross. 2004. Healthy and Unhealthy Emotion Regulation: Personality Processes, Individual Differences, and Life Span Development. $10.1111 / \mathrm{j} .1467-$ 6494.2004.00298.x.

Mc Cartney, K. \& Dearing, E., (Ed). (2002). Attachment. In Salkin, Neil J. Child Development (pp. 32-38). Mc Millan Refference USA.

Muhlisah, Leli. 2015. Hubungan antara Kelekatan Orangtua dengan Regulasi Emosi pada Remaja Awal. Yogyakarta : Universitas Islam Indonesia.

Papalia, D. E., Old s, S. W., \& Feldman, R. D. (2009). Human Development. (Perkembangan Manusia). Jakarta: Salemba Humanika.

Papworth, Brad. 2014. Attending Boarding School: A
Longitudinal Study of Its Role In Students' Academic and Non-Academic Outcomes. A thesis submitted for the degree of Doctor of Philosophy, Faculty of Education and Social Work, University of Sydney, Australia. (Online)

Rasyid, Miranti. 2012. Hubungan antara Peer Attachment dengan Regulasi Emosi Remaja yang Menjadi Siswa di Boarding School SMA Negeri 10 Samarinda. Jurnal Psikologi Pendidikan dan Perkembangan. Surabaya : Universitas Airlangga Surabaya.

Richards, J. M., \& Gross, J. J. (2000). Emotion Regulation and Memory: The Cognitive Costs of Keeping One's Cool. Journal of Personality and Social Psychology, 79(3), 410424. DOI: $10.1037 / 0022-$ 3514.79.3.410.

Santrock, John W. (2007). Perkembangan Anak Edisi Kesebelas Jilid 2. Jakarta : Penerbit Erlangga.

Santrock, John W. 2012. Perkembangan Masa Hidup Edisi Ketigabelas, Jilid I. Jakarta : Penerbit Erlangga.

Schaverien J. 2011a. Lost for Words. Theraphy Today. 22 (3)- 1821.

Schaverien, Joy. 2011b. British Journal of Psychotherapy. Vol. 27 Issue 2, p138-155. 18p. DOI: 10.1111j.17520118.2011.01229.x. 
Schaverien, Joy. 2015. Boarding

Psychological

Science

School Syndrome: The

19(6):352-357.

DOI:

Psychological Trauma of The

'Privileged' Child. DOI: 10.4324/9781315716305.

Sugiyono. 2015. Metode penelitian kuantitatif, kualitatif, dan kombinasi (mixed methods). Bandung : Alfabeta

Thompson, R. (1994). Emotion Regulation a Theme in Search of Definition. In N. Fox (Ed.)

Thompson, R. A. (1991). Emotional Regulation and Emotional Development. Educational Psychology Review, 3, 269307. DOI 10.1007/BF01319934

Urry \& Gross. 2010. Emotion Regulation in Older Age. Current Directions in 